

E-ISSN: 2664-942X

P-ISSN: 2664-9411

www.dermatologypaper.com

Derma 2021; 4(1): 14-16

Received: 15-10-2020

Accepted: 19-12-2020

Kanchan Srivastava

Assistant Professor,

Department of Dermatology,

Hind Institute of Medical

Sciences Ataria Sitapur,

Uttar Pradesh, India

Deepika Agarwal

Assistant Professor,

Department of Dermatology,

Hind Institute of Medical

Sciences Ataria Sitapur,

Uttar Pradesh, India

Dr. Himali Tandon

Assistant Professor,

Department of Dermatology,

Hind Institute of Medical

Sciences Ataria Sitapur,

Uttar Pradesh, India

Corresponding Author:

Dr. Himali Tandon

Assistant Professor,

Department of Dermatology,

Hind Institute of Medical

Sciences Ataria Sitapur,

Uttar Pradesh, India

\section{Assessment of cases of primary cutaneous lymphomas- A clinical study}

\author{
Kanchan Srivastava, Deepika Agarwal and Dr. Himali Tandon
}

DOI: https://doi.org/10.33545/26649411.2021.v4.i1a.56

\begin{abstract}
Background: Primary cutaneous lymphomas represent the second most common group of extranodal non-Hodgkin lymphoma after primary gastrointestinal lymphomas. The present study was conducted to assess cases of primary cutaneous lymphomas.

Materials and methods: 82 cases of primary cutaneous lymphomas both genders were recruited. Duration of illness, presence of pruritus, family history, and occupational history was recorded.

Results: Out of 82 patients, males were 48 and females were 34. Type of lesions were mycosis fungoides in 42, adult T-cell lymphoma/leukemia in 30 and peripheral T-cell lymphoma in 10 patients. Type of lesions were macules in 16 , papules in 20 , plaques in 22 , macules \& papules in 10 , papules \& plaques in 4 , pustules and nodules in 6 , plaques and nodules in 4 cases. The difference was significant $(P<0.05)$.

Conclusion: Type of lesions were mycosis fungoides, adult T-cell lymphoma/leukemia and peripheral T-cell lymphoma in 10 patients. Type of lesions were macules, papules, plaques, macules \& papules.
\end{abstract}

Keywords: Mycosis fungoides, adult T-cell lymphoma/leukemia and peripheral T-cell lymphoma

\section{Introduction}

Cutaneous lymphomas refer to the clonal proliferation of $\mathrm{T}$ or B lymphocytes and rarely of natural killer cells or plasmacytoid dendritic cells. Primary cutaneous lymphomas represent the second most common group of extranodal non-Hodgkin lymphoma after primary gastrointestinal lymphomas ${ }^{[1]}$. Sixty-five percent of cutaneous lymphomas are of T-cells unlike nodal lymphomas where B-cells predominate. The incidence of cutaneous lymphomas is showing an ascending trend which could be due to both improved diagnosis, as well as a genuine increase in disease incidence ${ }^{[2]}$.

Primary cutaneous $\mathrm{T}$ cell lymphomas is a heterogenous group of diseases with varied clinical presentations and prognosis. An annual incidence rate of new cases of cutaneous lymphomas of 1 in 100,000 people is estimated to occur in the United States ${ }^{[3]}$. Of primary cutaneous lymphomas, $75 \%$ are T-cell lymphomas, $25 \%$ are B-cell lymphomas, and less than $1 \%$ are NK-cell lymphomas ${ }^{[4]}$. Males are more affected than females, with a male to female ratio of 2 or 3 to 1 . The mean age at diagnosis is between 50 and 60 years of age; however, the disease may also occur in childhood. The use of new molecular, histological, and clinical criteria have enhanced the recognition of primary cutaneous $\mathrm{T}$ - and B-cell lymphomas. Compared to their nodal counterpart they have a different clinical behavior and therefore require a different treatment approach ${ }^{[5]}$. The present study was conducted to assess cases of primary Cutaneous lymphomas.

\section{Materials and Methods}

The present study was conducted on 82 cases of primary cutaneous lymphomas of both genders. Enrolment of patients was done after obtaining their consent.

Data such as name, age, gender etc. was recorded. Duration of illness, presence of pruritus, family history, and occupational history. Peripheral smear was evaluated for the total number of white blood cells, percentage of lymphocytes and atypical lymphocytes. Five milliliters of blood was collected and screened for human T-cell lymphotropic virus-1 (HTLV-1) antibodies. 
The diagnosis of the lymphoma type was established according to the World Health Organization/European Organization for Research and Treatment of Cancer (WHO/EORTC) classification 2005 and the data were analysis statistically. $\mathrm{P}$ value less than 0.05 was considered significant.

\section{Results}

Table 1: Distribution of patients

\begin{tabular}{|c|c|c|}
\hline \multicolumn{3}{|c|}{ Total- 82 } \\
\hline Gender & Males & Females \\
\hline Number & 48 & 34 \\
\hline
\end{tabular}

Table 1 shows that out of 82 patients, males were 48 and females were 34 .

Table 2: Primary cutaneous lymphomas

\begin{tabular}{|c|c|c|}
\hline Types & Number & P value \\
\hline Mycosis fungoides & 42 & \multirow{2}{*}{0.01} \\
\hline Adult T-cell lymphoma & 30 & \\
\hline Peripheral T-cell lymphoma & 10 & \\
\hline
\end{tabular}

Table 2, Figure 1 shows that type of lesions were mycosis fungoides in 42, adult T-cell lymphoma/leukemia in 30 and peripheral T-cell lymphoma in 10 patients. The difference was significant $(P<0.05)$.



Fig 1: Primary cutaneous lymphomas

Table 3: Type and frequency of skin lesions

\begin{tabular}{|c|c|c|}
\hline Type & Number & \multirow{2}{*}{ P value } \\
\hline Macules & 16 & \\
\hline Papules & 20 & \\
\hline Plaques & 22 & \multirow{2}{*}{0.02} \\
\hline Macules \& Papules & 10 & \\
\hline Papules \& Plaques & 4 & \\
\hline Pustules and nodules & 6 & \\
\hline Plaques and nodules & 4 & \\
\hline
\end{tabular}

Table 3, Figure 2 shows that type of lesions were macules in 16 , papules in 20 , plaques in 22 , macules \& papules in 10 , papules \& plaques in 4 , pustules and nodules in 6 , plaques and nodules in 4 cases. The difference was significant $(P<$ $0.05)$.

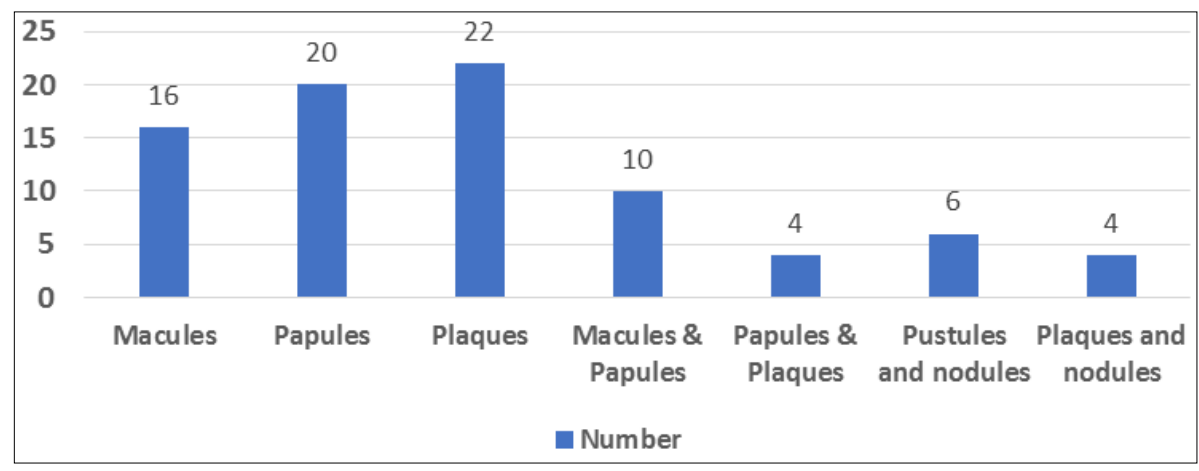

Fig 2: Type and frequency of skin lesions

Table 4: Site of lesions

\begin{tabular}{|c|c|c|}
\hline Site & Percentage & \multirow{2}{*}{ P value } \\
\hline Scalp & $40 \%$ & \multirow{2}{*}{0.01} \\
\hline Face & $25 \%$ & \\
\hline Chest & $12 \%$ & \\
\hline Back & $23 \%$ & \\
\hline
\end{tabular}

Table 4 shows that common sites were scalp in $40 \%$, face in $25 \%$, Chest in $12 \%$ and cack in $23 \%$. The difference was significant $(P<0.05)$.

\section{Discussion}

The diagnosis of primary cutaneous lymphomas is confirmed by a histopathology analysis, with neoplastic lymphocytes infiltrating the epidermis, dermis, and/or subcutaneous tissue. However, the immunohistochemical examination is essential to complement the classification of cutaneous lymphomas ${ }^{[6]}$. It initially differentiates among $\mathrm{T}$, $\mathrm{B}$, and $\mathrm{NK}$ cell lymphomas and then assists in classifying among these groups ${ }^{[7]}$. The search for the clonality of the TCR gene ( $T$ lymphocytes) or the heavy chains of immunoglobulins (B lymphocytes) is performed by polymerase chain reaction (PCR) or Southern blot and allows the detection of monoclonal populations, which are highly suggestive of malignant lymphoproliferative disorders. The search for clonality is a useful tool for differentiation between reactive lymphoproliferative processes (pseudolymphoma) and lymphomas ${ }^{[8]}$. The present study was conducted to assess cases of primary cutaneous lymphomas.

In present study, out of 82 patients, males were 48 and females were 34 . We found that type of lesions were mycosis fungoides in 42 , adult $\mathrm{T}$-cell lymphoma/leukemia in 30 and peripheral T-cell lymphoma in 10 patients. Khader et al. ${ }^{[9]}$ conducted a study among 35 cases, 33 (94.3\%) were T-cell, and $2(5.7 \%)$ were B-cell lymphomas. The mean age was 52.66, and the male to female ratio was $2.5: 1$. The most common types of T-cell lymphomas included mycosis fungoides (MF) (57.1\%) followed by adult T-cell lymphoma/leukemia (ATL) (17.1\%). Primary cutaneous peripheral T-cell lymphoma not otherwise specified was diagnosed in $17.1 \%$ and anaplastic large cell lymphoma in $2.9 \%$. The morphological types of MF included polymorphic, poikilodermatous, folliculotropic, 
hypopigmented, hyperpigmented, mixed and purpuric. Skin manifestations of ATL included ulcerated plaques and erythroderma. Epidermotropism was very marked in ATL $(83.3 \%)$ than in MF $(70 \%)$. Larger Pautrier's microabscess was noted in ATL compared to smaller ones in MF. Markedly dense, diffuse infiltrate of atypical cells was noted in ATL in contrast to mild to moderate nodular or perivascular infiltrate in MF. ATL had an extremely poor prognosis.

We found that type of lesions were macules in16, papules in 20 , plaques in 22 , macules \& papules in 10 , papules $\&$ plaques in 4 , pustules and nodules in 6 , plaques and nodules in 4 cases. We observed that common sites were scalp in $40 \%$, face in $25 \%$, Chest in $12 \%$ and cack in $23 \%$.

Mycosis fungoides (MF) is the most prevalent cutaneous $\mathrm{T}$ cell lymphoma (CTCL), corresponding to about $50 \%$ of all cutaneous lymphomas. It is a CD4+ effector memory T-cell neoplasm. MF is the only primary cutaneous lymphoma with no primary lymph node malignancy counterpart ${ }^{[10]}$. Indolent neoplasm with insidious progression can suffer a transformation to an aggressive large-cell lymphoma. It is composed of different clinical variants and characterized by marked epidermotropism ${ }^{[11]}$. Exposure to chemical agents like aromatic halogenated hydrocarbons in the petroleum, wood and textile industries, organochlorines in pesticides and paints, radiation, and tobacco are thought to be major risk factors for cutaneous T-cell lymphoma, especially MF. Other reported immunophenotypic variants of MF include CD4/CD8 double negative, CD45RA+, and CD20+. The former ones behave similar to classic MF although the latter appears to exhibit an aggressive clinical course. A single case of CD4/8 double negative MF in our study presented with hyperpigmented plaques and nodules and progressed to leukemic MF ${ }^{[12]}$.

\section{Conclusion}

Authors found that type of lesions were mycosis fungoides, adult T-cell lymphoma/leukemia and peripheral T-cell lymphoma in 10 patients. Type of lesions were macules, papules, plaques, macules $\&$ papules.

\section{References}

1. Samimi S, Rook AH, Kim EJ. Update on epidemiology of cutaneous T-cell lymphoma. Curr Derm Rep 2013; 2:35-41

2. Pavlovsky L, Mimouni D, Amitay-Laish I, Feinmesser M, David M, Hodak E. Hyperpigmented mycosis fungoides: An unusual variant of cutaneous T-cell lymphoma with a frequent CD8 + phenotype. J Am Acad Dermatol 2012; 67:69-75.

3. Al-Abdulrazzaq A, Zadeh VB, Al-Otaibi S, Najem N. Purpuric mycosis fungoides: A rare presentation of a great masquerade. Gulf J Dermatol Venereol 2011; 18:47-9.

4. Thompson D, Whittaker S. Cutaneous manifestations of HTLV-1. J Am Acad Dermatol 2006; 54(3):153.

5. Chan HL, Su IJ, Kuo TT, Kuan YZ, Chen MJ, Shih LY et al. Cutaneous manifestations of adult $\mathrm{T}$ cell leukemia/lymphoma. Report of three different forms. J Am Acad Dermatol 1985; 13:213-9.

6. Kawakami T, Kawanabe T, Soma Y. Granuloma annulare-like skin lesions as an initial manifestation in a Japanese patient with adult T-cell leukemia/lymphoma. J Am Acad Dermatol 2009; 60:848-52.
7. Sumida H, Sugaya M, Kamata M, Suga H, Miyagaki T, Ohmatsu $\mathrm{H}$ et al. Lichen planus-like lesions as the first manifestation of adult T-cell leukaemia/lymphoma. Acta Derm Venereol 2013; 93:461-3.

8. Manabe T, Hirokawa M, Sugihara K, Sugihara T, Kohda M. Angiocentric and angiodestructive infiltration of adult T-cell leukemia/lymphoma (ATLL) in the skin. Report of two cases. Am J Dermatopathol 1988; 10:487-96.

9. Khader A, Manakkad SP, Shaan M, Pillai SS, Riyaz N, Manikoth PB et al. A clinicopathological analysis of primary cutaneous lymphomas: A 6-year observational study at a tertiary care center of south India. Indian $\mathrm{J}$ Dermatol 2016; 61:608-17.

10. Whittaker SJ, Child S. Cutaneous lymphomas. In: Griffiths C, Barker J, Bleiker T, Chalmers R, Creamer D, editors. Rook's Text Book of Dermatology. 9th ed. UK: Wiley-Blackwell; 2016; 140:39.

11. Willemze R, Jaffe ES, Burg G, Cerroni L, Berti E, Swerdlow SH et al. WHO-EORTC classification for cutaneous lymphomas. Blood 2005; 105:3768-85.

12. Doshi BR, Khopkar US. Retrospective study of spectrum of cutaneous lymphoma presenting to dermatology. Indian J Dermatol Venereol Leprol s2011; 77:512-5. 